\title{
Zadania opata określone w prawodawstwie monastycznym kręgu św. Fruktuoza z Bragi
}

Rozwijające się w pierwszych wiekach chrześcijaństwa klasztory potrzebowały organizacji, która była niekiedy szczegółowo określana przez autorów reguł zakonnych. Dotyczyło to zarówno wyznaczenia funkcji oraz zadań z nimi związanych, jak i całej sfery duchowej, która stanowiła drogę do osiągnięcia doskonałości chrześcijańskiej. Przykładem praktycznych wskazań kierowanych do mniszek i mnichów są pisma monastyczne, które pozostawili pisarze żyjący na Półwyspie Iberyjskim, na terenach dzisiejszej Hiszpanii i Portugalii. Najstarsze ślady monastycyzmu na tych ziemiach spotykamy w IV wieku, największy natomiast rozkwit życia zakonnego nastąpił tam w wieku VI i VII. Z tego też okresu pochodzą reguły zakonne, które wyszły spod pióra trzech wielkich postaci Kościoła hiszpańskiego nazywane regułami iberyjskimi².

\footnotetext{
1 Ks. prof. dr hab. Bogdan Czyżewski, kapłan archidiecezji gnieźnieńskiej, profesor nauk teologicznych, wykładowca patrologii, historii Kościoła starożytnego i języków klasycznych na Wydziale Teologicznym Uniwersytetu im. Adama Mickiewicza w Poznaniu, kierownik Zakładu Teologii Historycznej WT UAM, prezes Sekcji Patrystycznej; e-mail: czybo@amu.edu.pl; ORCID: 0000-0002-6040-5523.

2 Por. M. Starowieyski, Monastycyzm na Półwyspie Iberyjskim, w: Zachodnie reguty monastyczne, ŹM 50, Tyniec 2013, s. 903-908. Chodzi tutaj o św. Leandra z Sewilli, jego brata św. Izydora z Sewilli oraz św. Fruktuoza z Bragi.
} 
W niniejszym opracowaniu zajmiemy się jednym z nich, mianowicie św. Fruktuozem z Bragi (ok. 600-665)³. Pochodził ze znakomitej rodziny gockiej i był synem dowódcy wojskowego. Zakładał liczne klasztory, które uposażał z własnych dóbr. Był najpierw opatem-biskupem klasztoru w Dumio, następnie zaś biskupem w Bradze, w którym prowadził życie mnisze, podobnie jak św. Marcin z Tours ${ }^{4}$. Św. Fruktuozowi przypisuje się trzy pisma o tematyce monastycznej5: Regułę mnichów (Regula monachorum) ${ }^{6}$, Regułę wspólną (Regula communis $)^{7}$ i Pakt (Pactum) $)^{8}$. Pierwsze z nich napisał św. Fruktuoz. Reguła ta posiada silny związek z monastycyzmem wschodnim9. Zawiera liczne

3 O życiu i działalności zakonnej św. Fruktuoza powstało kilka ważnych opracowań: M. Martins, O monacato de S. Fructuoso de Braga, „Biblos” 26 (1950) s. 315-420; M.C. Díaz y Díaz, La vida de San Fructuoso de Braga: estudio y edición critica, Braga 1974; A. Linage Conde, San Benito y las Fuentes literarias de la obra monástica de Fructuoso de Braga, Studia Patristica XIX-XXIII, Leuven 1989, s. 264-273; F. Drączkowski, Fruktuoz, EK V 729; J. López Quiroga, Actividad Monástica y acción política en Fructuoso de Braga, „Hispania sacra. Revista española de historia ecclesiástica" 54 (2002) s. 7-22; Ch. J. Bishko, Fructuosus of Braga, w: Medieval Iberia. An encyclopedia, red. E.M. Gerli, New York 2003, s. 342-343; H. Pettiau, La Vie de saint Fructueux de Braga: Quelques aspects de la relation entre l'ascète et la société en Espagne wisigothique, w: Corona Monastica: moines bretons de Landévennec, histoire et mémoire celtiques: mélanges offerts au père Marc Simon, ed. L. Lemoine - B. Merdrignac A. Calarnou, Britannia Monastica 8, Landévennec 2004, s. 57-69.

4 Por. Starowieyski, Monastycyzm na Pólwyspie Iberyjskim, s. 1031-1034.

5 Pisma monastyczne św. Fruktuosa z Bragi doczekały się kilku opracowań, m.in. I. Herwegen, Das Pactum des hl. Fructuosus von Braga, Stuttgart 1907; R. Gregoire, Valeurs ascétiques et spirituelles de la Regula monachorum et de la Regula communis de s. Fructueux de Braga, „Revue d'ascétique et de mystique” 43 (1967) s. 159-178; A. Linage Conde, El torno de la Regula monachorum y sus relaciones con otras Reglas monásticas, „Bracara Augusta” 22 (1968) s. 123-163; J. Pérez de Urbel, Regula complutensis (Regula S. Fructuosi), w: DIP VII 1759-1771.

6 Św. Fruktuoz, Reguła mnichów, tł. P. Wygralak, w: Zachodnie reguly monastyczne, ŹM 50, Tyniec 2013, s. 1049-1076.

7 Św. Fruktuoz, Reguła wspólna, tł. A. Strzelcka, w: Zachodnie reguły monastyczne, ŹM 50, Tyniec 2013, s. 1077-1118.

8 Pakt, tł. A. Strzelcka, w: Zachodnie reguly monastyczne, ŹM 50, Tyniec 2013, s. $1119-1123$.

9 Chodzi tutaj przede wszystkim o Regułę św. Pachomiusza czy też Institutiones św. Jana Kasjana. Więcej na temat tego wpływu, zob. M.C. Díaz y Díaz, Fructueux de Braga (saint), w: Dictionnaire de Spiritualité, t. 5, ed. M. Viller, Paris 1964, s. 1541-1546. 
praktyczne przepisy odnoszące się do codziennego życia w założonym przez niego klasztorze. Drugie pismo, Reguła wspólna, nie jest autorstwa św. Fruktuoza, niektóre jednak jego fragmenty powstały prawdopodobnie za czasów Fruktuoza, stąd też zaliczane bywa do dokumentów monastycyzmu fruktuozjańskiego. Do Reguły wspólnej dołączone jest trzecie pismo o nazwie Pakt. Ten krótki dokument prawny, typowy dla monastycyzmu iberyjskiego, to akt zgody składanej przez mnichów i opata w czasie uroczystej ceremonii liturgicznej, w którym wszyscy zobowiązywali się do jego przestrzegania ${ }^{10}$.

Wymienione trzy pisma pozostające w związku $\mathrm{z}$ działalnością św. Fruktuoza z Bragi i przechowywane pod jego imieniem zawierają niemało informacji na temat funkcji opata (abbas), który był najważniejszą osobą w całej zakonnej strukturze. W niniejszym opracowaniu spróbujemy przedstawić jego zadania nakreślone w prawodawstwie monastycznym kręgu św. Fruktuoza z Bragi. Okazuje się bowiem, że przepisy odnoszące się do opata dotyczą różnych wymiarów życia klasztornego. Dlatego zanalizujemy wszystkie teksty Regut św. Fruktuoza, w których jest mowa o opacie i zapytamy najpierw o przymioty, jakimi musiał się on odznaczać. Przyjrzymy się również przepisom odnoszącym się do organizowania przez opata modlitwy w klasztorze, dalej wskażemy na inne codzienne zadania, jakimi obarczał go prawodawca, w końcu poznamy jego postawę wobec grzesznych mnichów oraz chorych i starszych mieszkańców klasztoru. Mamy nadzieję, że analizowane pod tym kątem Reguły pochodzące z kręgu monastycznego św. Fruktuoza z Bragi pokażą w miarę obiektywny i całościowy obraz opata, któremu każda reguła dawała $\mathrm{z}$ jednej strony władzę w zakonie, ale też odpowiedzialność za siebie $\mathrm{i}$ innych.

10 Por. M. Starowieyski, Fruktuoz, bp Bragi, NSWP, Poznań 2018, s. 375. 


\section{Wymagania stawiane opatowi}

W Regule mnichów czytamy, że „opata lub przełożonego zawsze należy wybierać spośród mnichów własnego klasztoru" ${ }^{11}$. Oznacza to, że nie mogła nim zostać osoba, która przybyła do wspólnoty mnichów z zewnątrz. Po tym ogólnym stwierdzeniu św. Fruktuoz szczegółowo wylicza gamę przymiotów, jakimi powinien odznaczać się opat. Autor Reguły mnichów nie układa ich systematycznie, raczej miesza ze sobą cechy odnoszące się do podstawowych wymiarów życia mnicha i umieszcza je w różnych miejscach swoich pism monastycznych. Można jednak wydobyć z nich poszczególne przymioty i nazwać je wymaganiami natury ludzkiej, chrześcijańskiej i intelektualnej.

Najpierw skupimy uwagę na przymiotach charakterystycznych dla postawy ludzkiej opata. Prawodawca uważa, że kandydat na opata powinien być roztropny, poważny, lubiany przez innych, ma gardzić wymyślnymi posiłkami i upodobaniem do bogato zastawionych stołów, nie wolno nadużywać mu wina. Poza tym nie powinien popadać w nagłą złość i być porywczym, ale ma kierować się cierpliwością, łagodnością i pokorą. Musi unikać też pychy i pamiętać, że chociaż piastuje tak wysoką godność w klasztorze, to jednak jest sługą dla potrzebujących i biednych, co więcej nie powinien uważać „siebie wyłącznie za przełożonego"12. Musi mieć też prawdziwie ojcowskie podejście do współbraci i być dla nich ,jak ich własny i najbardziej kochający ojciec"13. Do ludzkich cech, jakimi ma odznaczać się opat, można dodać również wymaganie, by nigdy nie pogrążał się w smutku i małoduszności, nie powinien też ulegać żadnej pożądliwości ${ }^{14}$.

Niezwykle ważne wydają się przymioty chrześcijańskie, które prawodawstwo monastyczne kręgu św. Fruktuoza stawia przez opatem.

\footnotetext{
Regula monachorum XIX.

12 Regula monachorum XIX.

13 Regula monachorum XIX.

14 Por. Regula monachorum XIX.
} 
Na pierwszym miejscu została wymieniona świętość, dalej roztropność i czystość ${ }^{15}$. Z kolei w Regule wspólnej mowa jest najpierw o trwałym przywiązaniu do świątobliwego życia, co oznacza, że opatem nie może być człowiek ,dopiero co nawrócony do życia monastycznego, lecz taki, który przez długi czas pracuje w klasztorze w pocie czoła, poddany władzy opackiej” "16. Autor Reguły mnichów zwraca także uwagę na doświadczenie opata w życiu zakonnym. Oznacza to, że pomyślnie przechodził różnorakie próby i dobrze poznał przepisy odnoszące się do życia zakonnego zawarte w Regule oraz żyje nimi na co dzień ${ }^{17}$. Prawodawca bliżej nie precyzuje, o jakie tutaj próby chodzi. Prawdopodobnie miał na myśli wytrwałość $\mathrm{w}$ pokorze, która w klasztorze bardzo była ceniona, wolność od posiadania czegokolwiek, ale też radzenie sobie z pokusami, na jakie narażony był każdy mnich. Fruktuoz podkreśla także potrzebę zgodności przepowiadania z życiem. Inaczej mówiąc, nauczanie opata musiało być odzwierciedlone w jego postępowaniu, dlatego też „powinien wykazywać tak wielką zgodność swych słów ze swoim życiem, aby wszystko, czego nauczał przez słowa, potwierdzał przez szczere uczynki”" Wspomniana zgodność porównana została do współbrzmienia ,ze sobą struny liry albo cytry, które tylko wtedy wydają słodki dźwięk, kiedy są uderzane ręką artysty z zachowaniem właściwego umiaru, bez szarpania z gwałtownością, rodzącą dysharmonię"19.

Pośród wymagań stawianych opatowi można dostrzec też cechy natury intelektualnej. Prawodawca z Bragi zwraca bowiem uwagę na to, by opat był człowiekiem uczonym i błyszczał wiedzą. Nie chodzi tutaj jednak o popisywanie się intelektualnymi zdolnościami, co raczej o wiedzę, która pozwoli mu uczyć innych ${ }^{20}$. Istniał bowiem w Regule mnichów

\footnotetext{
15 Por. Regula monachorum XIX.

16 Regula communis III.

17 Por. Regula monachorum XIX.

18 Regula monachorum XIX.

19 Regula monachorum XIX.

20 Por. Regula monachorum XIX.
} 
przepis mówiący o tym, że „po północy, podczas zimy, wszyscy siedząc razem wysłuchują lektury czytanej przez jednego z mnichów, siedzącego pośrodku. Mniej wykształconym wyjaśni jej treść opat lub przełożony"21. Dlatego też funkcję opata mógł spełniać ktoś, kto posiadał odpowiednią wiedzę i potrafił przekazać ją innym ${ }^{22}$.

Oprócz wymienionych cech, które nazwaliśmy ludzkimi, chrześcijańskimi i intelektualnymi, prawodawca zwraca jeszcze uwagę na wymóg dotyczący podejścia przyszłego opata do dóbr materialnych. Autor Reguły wspólnej poświęca temu zagadnieniu nieco miejsca. Zabrania wyboru opata, który jest przywiązany do majątku, a co za tym idzie, do procesowania się z ludźmi i prowadzenia z nimi różnego rodzaju sporów sądowych. Powinien tego unikać, nawet kiedy wie, że został oszukany i ma prawo dochodzić swojej sprawiedliwości. Kiedy natomiast coś będzie zagrażało majątkowi klasztoru, też zabrania się mu toczenia sporów sądowych z ludźmi świeckimi. W takiej sytuacji opat powinien zlecić obronę zakonu i jego mienia zaufanej i uczciwej osobie świeckiej²3.

Więcej przepisów na temat wyboru i przymiotów wymaganych od kandydatów na opata nie ma w regułach monastycyzmu kręgu fruktuozjańskiego. Kierowanie się jednak przy wyborze opata wymienionymi cechami z całą pewnością dawało gwarancję, że będzie to osoba

21 Regula monachorum II.

22 Św. Hieronim w jednym ze swoich listów pisze o podobnym zwyczaju panującym u cenobitów: „Po godzinie dziewiątej schodzą się wszyscy razem, śpiewają psalmy, czytają według zwyczaju Pismo Święte, a po skończeniu wszystkich modlitw siedzący w samym środku, ten, którego nazywają ojcem, zaczyna rozprawiać. Gdy on mówi, tak wielkie panuje milczenie, że nikt ani popatrzeć na drugiego nie śmie, ani chrząknąć" (Hieronymus, Epistula 22, 35).

23 Por. Regula communis III: Opat „tak dalece powinien więc wyzbyć się przywiązania do majątku, że z korzeniami wyrwie ze swego serca wszelki zwyczaj procesowania się. Gdyby nawet było to sprawiedliwe, niech nie podejmuje na drodze sądowej żadnego sporu z ludźmi [...]. Jeśli zaś nadejdzie jakiś prześladowca klasztoru i spróbuje czymś zawłaszczyć oraz zechce gwałtem coś zabrać, niech zleci sprawę jednemu z ludzi świeckich, najwierniejszemu chrześcijaninowi, którego wysoko ceni za dobre życie i nie uważa za niegodnego z powodu złej opinii”. 
godna i poradzi sobie z pełnieniem tej trudnej, a jednocześnie i zaszczytnej funkcji.

Wymienione powyżej przymioty chrześcijańskie stawiane opatowi odnaleźć można także w Regule św. Izydora z Sewilli, której autor wiele uwagi poświęca funkcji określanej jako pater monasterii ${ }^{24}$. Biskup Sewilli, podobnie jak Fruktuoz, jest świadomy tego, że życie opata powinno być prowadzone na najwyższym poziomie i winno odznaczać się takimi przymiotami moralnymi, które pozwolą mu właściwie kierować wspólnotą mnichów ${ }^{25}$. Z całą jednak pewnością św. Fruktuoz bardziej niż św. Izydor rozwinął przepisy odnoszące się do wymagań stawianych opatowi.

\section{Troska opata o modlitwę w klasztorze}

Reguły św. Fruktuoza zawierają także przepisy odnoszące się do czuwania opata nad życiem modlitewnym w klasztorze. Ta troska musi najpierw przybrać formę osobistego świadectwa. W Regule mnichów czytamy, że „opat i przełożony mają obowiązek uczestniczyć zawsze w oficjach i wigiliach, gdyż muszą sami czynić to, czego nauczają innych"26. Jest tutaj wyraźne odniesienie do tego, o czym była mowa przy wyborze opata, że powinna istnieć zgodność jego nauczania z życiem, które prowadzi. O postępowaniu zgodnym z tym, czego naucza opat, mowa jest też w Regule wspólnej ${ }^{27}$.

Z funkcją opata związany był też obowiązek pilnowania tak zwanych godzin kanonicznych. Najpierw chodziło o organizowanie w odpowied-

24 Por. Isidorus Hispalensis, Regula II.

25 Więcej na ten temat, zob. B. Czyżewski, Funkcje w Klasztorze Honoriańskim na podstawie Reguly św. Izydora z Sewilli, „Studia Gnesnensia” 39 (2015) s. 173-181.

26 Regula monachorum II.

27 Por. Regula communis X: „Po trzecie, powinni sami żyć w zgodzie z tym, co nakazują i przywołani do porządku wracać do cel, jak gdyby zmuszani przez dozorców”. 
nich porach dnia i nocy modlitwy brewiarzowej. Każda bowiem z tych godzin, począwszy od jutrzni a skończywszy na komplecie, posiada swoje uzasadnienie w Piśmie Świętym ${ }^{28}$. Wspomniane zadanie obejmowało też obowiązek odprawiania godzin kanonicznych w klasztorze „w obecności całej wspólnoty mnichów, z wielkim zaangażowaniem ducha, płaczem i ukorzeniem serca" ${ }^{29}$. Opat zwolniony był z tej służby tylko w przypadku, kiedy musiał podjąć konieczną pracę lub udać się w podróż. Drugi powód, czyli konieczność podróży, nie zwalniała jednak opata od modlitwy. W Regule wspólnej czytamy bowiem, że kiedy zbliżała się dana godzina kanoniczna, opaci „niech leżąc na ziemi nieustannie proszą Pana o przebaczenie. Podczas prywatnego odprawiania godzin, to znaczy sekundy, kwarty, kwinty, septymy, oktawy, decymy i undecymy niech się nie lenią w modlitwie" ${ }^{30}$. Wynika $\mathrm{z}$ tego, że co godzinę opat miał się modlić we wspólnocie lub też prywatnie.

O modlitwie wspomina też prawodawca przy okazji regularnych, comiesięcznych „synodów opackich”, które miały dwa podstawowe zadania. Pierwsze to odbycie wspólnej modlitwy przez opatów z różnych klasztorów. Ta zaś, jak i samo spotkanie prowadziły do drugiego celu, mianowicie tworzyły się rodzinne więzy pomiędzy mieszkańcami klasztorów św. Fruktuoza. Autor Reguły wspomina, że „opaci mieszkający po sąsiedzku zbierają się w jednym miejscu i gorliwie oraz uroczyście odprawiają comiesięczne litanie, błagając pomocy Bożej dla dusz swoich podwładnych"31.

28 Por. Regula communis X: „Przede wszystkim winni pilnować godzin kanonicznych, to znaczy prymy - na pamiątkę rozesłania robotników do winnicy; tercji - kiedy Duch Święty zstąpił na apostołów; seksty - kiedy ukrzyżowano Pana; nony - kiedy [Pan] oddał ducha. Wieczornej zaś, gdy Dawid śpiewał: Wzniesienie rąk moich - jak ofiara wieczorna (Ps 141,2); natomiast o północy - jako że w tej godzinie rozległo się wołanie: Oto pan młody idzie, wyjdźcie mu na spotkanie (Mt 25,6) [...] jutrzni z kolei, ponieważ Chrystus o tej porze powstał z martwych".

${ }_{29}$ Regula communis X.
${ }_{30}$ Regula communis X.
${ }_{31}$ Regula communis X. 
Przepisy odnoszące się do modlitwy i odpowiedzialność opata za jej odmawianie w odpowiedniej porze dnia nie mogą dziwić chociażby z tego powodu, że w klasztorach zwracano dużą uwagę na duchową stronę życia zakonnego. Modlitwa pozwalała wchodzić mnichowi w kontakt z Bogiem, kształtowała jego postawy, pomagała też znosić wszelkie trudy życia zakonnego.

\section{Codzienne zadania opata}

Reguły wspólnot fruktuozjańskich wymieniają cały szereg codziennych zadań opata. Decydował on o przyjmowaniu do klasztoru tak zwanych konwersów, czyli tych, którzy postanowili porzucić świat doczesny i wstąpić do klasztoru. Tacy kandydaci byli poddawani próbom przez pracę, ubóstwo, obelgi i zniewagi. Dopiero po pozytywnym przejściu tych różnorodnych doświadczeń opat lub najbardziej sprawiedliwi bracia podejmowali postanowienie o przyjęciu go do wspólnoty ${ }^{32}$.

Reguła wspólna mówi też o istnieniu tak zwanych podwójnych klasztorów, to znaczy takich, do których przyjmowano małżonków z małymi dziećmi, które nie ukończyły siedmiu lat. W tym przypadku zarówno rodzice, jak i dzieci oddani byli pod władzę opata, ten zaś pouczał ich o obowiązkach i zasadach panujących w klasztorze ${ }^{33}$.

Autor Reguł zwraca uwagę nie tylko na zadania opata, ale też podkreśla obowiązek posłuszeństwa mnichów względem niego aż do śmierci,

32 Por. Regula monachorum XX-XXII.

33 Por. Regula communis VI: „Święta Reguła wspólna postanowiła, że kiedy przychodzi do klasztoru ktoś razem z żoną i małymi dziećmi, które nie ukończyły siedmiu lat, tak rodzice jak i dzieci powinni oddać się pod władzę opata. Opat z całą odpowiedzialnością ma obowiązek dokładnie przedstawić im zasady, których muszą przestrzegać [...]. Zarówno rodzice jak i klasztor muszą troszczyć się o dzieci, dopóki choć w niewielkim stopniu nie pojmą one reguły, oraz nieustannie je wychowywać, aby zarówno chłopcy jak i dziewczynki zyskali w przyszłości powołanie do życia w klasztorze". 
ponieważ tylko w taki sposób można podążać za Chrystusem ${ }^{34}$. Opatowi należy również zawsze mówić prawdę i poddawać się jego osądowi, który jest dla mieszkańców klasztoru gwarancją trwania na właściwej drodze ${ }^{35}$.

Prawodawca analizowanych Reguł zdaje sobie sprawę z tego, że na opacie ciążą liczne obowiązki, dlatego stara się odciążyć go od niektórych zadań, jak chociażby zarządzanie majątkiem klasztoru, które należało do przełożonych. Mieli to być mnisi podobni w postępowaniu do opatów, by „mogli ulżyć ciężarowi opackich trosk”36. Chociaż przełożeni mieli dużą władzę we wspólnocie, o czym można było się przekonać, że często stawia się ich obok opata, to jednak zawsze podlegali jego osądowi i musieli, podobnie jak inni współbracia, okazywać mu posłuszeństwo ${ }^{37}$.

Opat posiadał też wiele zadań związanych z codziennym życiem w klasztorze. Mnich nie mógł podejmować, rozpoczynać lub wykonywać jakiejkolwiek pracy „,bez polecenia i pozwolenia przełożonego. W każdej sprawie musi zostać wykonane polecenie opata lub przełożonego"38. Opat w czasie jutrzni odprawianej w kościele udzielał błogosławieństwa tak zwanym hebdomadariuszom, którzy podejmowali tygodniową służbę. Wspomniane błogosławieństwo opata połączone było z modlitwą. Kiedy zaś w sobotę kończyli swój dyżur, po nieszporach obmywano im stopy ciepłą wodą, następnie zaś, „leżąc przed opatem [...] prosili zgromadzenie wszystkich braci o przebaczenie i błogosławieństwo"39.

Do opata należało też przekazywanie odpowiedzialnym za odzież w klasztorze narzędzi do ich naprawiania, czyli szydeł, igieł, różnego rodzaju nici do szycia, jej cerowania i łatania ubrań mnichów. Kiedy natomiast mnich otrzymywał nową odzież, stare jego ubrania, buty i pościel opat miał obowiązek przekazać ludziom ubogim ${ }^{40}$. Opaci

\footnotetext{
34 Por. Regula communis V.

35 Por. Regula communis V.

36 Regula communis XI.

37 Por. Regula communis XI.

38 Regula monachorum IV.

39 Regula monachorum VII.

40 Regula monachorum XI.
} 
bądź przełożeni przeglądali również dwa razy w tygodniu łóżka mnichów. Chodziło o sprawdzenie, czy czegoś w nich nie ukrywają lub nie przetrzymują zbędnych rzeczy ${ }^{41}$. Tym samym zwracano uwagę na konieczność prowadzenia życia ubogiego, bez przywiązywania się do czegokolwiek.

W klasztorze pozwalano mnichom pić niewielką ilość wina. Było to około pół litra rozdzielone pomiędzy czterech zakonników. Opat lub przełożony miał w tym względzie ostateczny głos, należało bowiem uwzględnić ich zalecenia ${ }^{42}$. Prawdopodobnie chodziło o zwiększenie bądź też zmniejszenie proponowanej przez Regutę codziennej porcji tego napoju. Tak bywało w przypadku obowiązkowych postów, w czasie których mnisi nie mogli pić wina. Nie oznaczało to jednak całkowitego zakazu, ponieważ w Regule mnichów czytamy, iż w tym względzie należy ,podporządkować się mądrości opata, który widząc, że mnisi są zmęczeni przez ciężką pracę, pozwoli im czasem na wypicie w czasie posiłku jednej miary wina na osobę"43. Prawodawca zwracał też uwagę na to, by opat dbał o wspólnotę stołu w klasztorze. Wszyscy mieli spożywać posiłki razem, chyba że opat musiał podejmować ,przybywających podróżnych lub dostojnych duchownych"44. Zasada jednak była ta sama dla każdego: to samo jedzenie dla wszystkich i niczego nie powinno się jeść poza wspólnymi posił$\mathrm{kami}^{45}$. Mnichowi nie wolno było bez pozwolenia opata lub przełożonego wysyłać listy w jakieś miejsce albo też potajemnie odbierać od kogoś listów adresowanych do siebie ${ }^{46}$.

\footnotetext{
41 Por. Regula monachorum XVI.

42 Por. Regula monachorum III.

43 Regula monachorum XVII.

44 Regula monachorum XVIII.

45 Por. Regula communis X. Podobny przepis odnajdujemy w regule Pachomiusza.
} Por. Praecepta 35 oraz Institutiones (III 1.7) św. Jana Kasjana.

46 Por. Regula monachorum XV. 


\section{Postępowanie wobec grzesznych mnichów}

Oprócz tego, że Reguty św. Fruktuoza wykazywały związek z monastycyzmem wschodnim, drugą cechą charakterystyczną była ich surowość. Dlatego też zawierają wiele wskazań dotyczących kar stosowanych wobec mnichów za ich nieposłuszeństwo. Opat jawi się w tych sytuacjach jako ten, który ma być miłosierny i zarazem sprawiedliwy. Mnich, który z powodu swoich wykroczeń został wykluczony ze wspólnoty, po czynieniu pokuty i modlitwie otrzymywał przebaczenie i został „,rozgrzeszony dzięki litości mnichów i miłosierdziu opata”47.

Z kolei Reguła wspólna zawiera szereg wskazań odnoszących się do mnichów ekskomunikowanych. Postępowanie względem nich miało polegać na tym, by uświadomili sobie popełnioną winę. Zamknięty samotnie mnich w ciemnej celi dopiero wieczorem otrzymywał niewielką ilość chleba i wody. Przepis mówi, że nad takim mnichem „niech opat wyda tchnienie, ale nie błogosławieństwo"48. Nie może też odzywać się, chyba że opat lub przełożony mocą swej władzy wyrażą na to zgodę ${ }^{49}$. Uwolnienie z ekskomuniki trwało najczęściej kilka dni, podczas których winowajca był doświadczany w pokorze i sprawdzany, czy jego nawrócenie i skrucha są autentyczne. Opat stosował przy tym różnego rodzaju próby odnoszące się do pokory grzesznika, by przekonać się o prawdziwości jego żalu. Nawet po pozytywnym potwierdzeniu ze strony trzech świadków opat kazał takiego mnicha przepędzić i karcił go przed całą wspólnotą. Powrót do zakonu na wcześniej zajmowane miejsce dokonywał się najczęściej czwartego dnia po wykluczeniu ze wspólnoty. Ekskomunikowany mnich „trzymając w rękach sznur” rzucał się ,ze łzami do stóp opata czy też braci" ${ }^{50}$ i błagał na kolanach o okazanie mu łaski

47 Regula monachorum XIII. Podobny przepis, por. Isidorus Hispalensis, Regula monachorum XVIII.

48 Regula communis XIV.

49 Por. Regula communis XIV.

50 Regula communis XIV. 
przebaczenia. Po kolejnym upomnieniu otrzymywał wreszcie pocałunek pokoju od opata i zostawał na nowo przyjęty do wspólnoty ${ }^{51}$.

Dla opata nie były to łatwe zadania, musiał on bowiem z jednej strony być surowym wobec grzechów popełnianych przez powierzonych mu mnichów, z drugiej zaś okazywać miłosierdzie, badając przy tym dokładnie autentyczność żalu i nawrócenia winowajcy. Było to o tyle ważne, że przy braku oznak pokuty i pokory ekskomunikowany mnich był wydalany z szeregów zakonnych, a decyzję taką musiał zapewne podjąć opat ${ }^{52}$.

Jak istotne było właściwe rozeznawanie przez opata motywów postępowania mnichów, świadczą przepisy dotyczące ich sądzenia. Mogło bowiem dojść do sytuacji, w której któryś z młodych mnichów został podstępnie lub złośliwie oskarżony przez starszego mieszkańca klasztoru. W Regule mnichów czytamy, że w takiej sytuacji ,zakazuje się opatowi lub przełożonemu wydawać sąd przez wzgląd na osobę albo skazywać kogoś przewrotnie lub niesprawiedliwie"s3. Reguła poleca opatowi, aby będąc niepewnym oskarżeń, powołał „trybunał złożony z pobożnych i prawdomównych braci, którzy mając na względzie sąd Boży nie pozwolą na haniebne oskarżanie niewinnego" ${ }^{4}$. Dlatego też prawodawca przestrzega przed zbyt pochopnymi sądami i wymaga od opata oraz przełożonych, by wymierzali kary mądrze, stosownie do popełnionej winy. Zarówno opat, jak i przełożony „powinni odznaczać się umiarem i prawością, miłosierną sprawiedliwością i stałym współczuciem" ${ }^{55}$. Zadaniem kary bo-

51 Por. Regula communis XIV. Podobny przepis zawarł w swojej regule św. Benedykt (por. Regula 27).

52 Por. Regula communis XIV: „,...] jeśli nadal będzie zatwardziały w złym i odmówi dobrowolnie skruchy, coraz częściej okazując hardość i szemrając otwarcie przeciw starszemu albo braciom, a także zechce z pomocą krewnych dochodzić swych praw, doprowadzony na zebranie wspólnoty niech zostanie pozbawiony szat zakonnych i przyodziany w rzeczy, które nosił dawniej, w świecie. Niech z piętnem wstydu odejdzie z klasztoru, aby reszta braci mogła naprawić swe błędy, gdyż może choć jeden zmieni na lepsze swe postępowanie, widząc taką naganę, którą poniósł sam grzesznik".

\footnotetext{
53 Regula monachorum XIII.

${ }_{54}$ Regula monachorum XIII.

55 Regula monachorum XIV.
} 
wiem nie mogło być dalsze pogłębianie słabości grzesznika, ale leczenie jego ran i prowadzenie do nawrócenia. Autor Reguły z całą surowością i realizmem przestrzega opata, że jego winy zostaną osądzone przez samego Boga w taki sam sposób, w jaki on osądził winy podwładnych ${ }^{56}$.

Opat zobowiązany był także do wysłuchania mnicha, który zdawał mu ,sprawozdanie ze wszystkich swoich czynów i okoliczności, w których musiał je podjacć" ${ }^{57}$. Chodziło tutaj o wyznanie grzechów przed opatem, ten zaś miał „rozeznać $z$ roztropnością i osądzić, na co powinien zwrócić uwagę" 58 mnich w dalszej pracy nad sobą. Prawodawca zobowiązuje opata, by były to z jego strony słowa pociechy, modlitwy i upomnienia, które prowadziły do poprawy życia ${ }^{59}$. Wyznanie grzechów przed opatem odbywało się także w przypadku mnichów, którzy w życiu świeckim popełnili grzechy ciężkie. Jemu, ,,jak chorzy lekarzowi [...] wyznali wszystkie popełnione grzechy"60. Pytanie o popełnione grzechy, zwłaszcza o nienawiść względem drugiego, padało ze strony opata w niedzielę, przed Mszą Świętą. Wcześniej jednak temu badaniu sumienia poddawali się opaci, przełożeni i dziekani ${ }^{61}$.

Pozostała jeszcze jedna ważna kwestia, mianowicie osąd opata przez wspólnotę. Załączony do Reguł Pakt zobowiązywał nie tylko do przestrzegania obowiązków zakonnych przez jedną stronę, to znaczy przez mnichów. Także opat był związany tą umową. Odnośnie do tego czytamy

\footnotetext{
56 Por. Regula monachorum XIV.

57 Regula monachorum XII.

58 Regula monachorum XII. Podobnie u św. Jana Kasjana (Institutiones IV 9).

59 Por. Regula monachorum XII.

60 Regula communis XIX.

61 Por. Regula communis XIII: „Przełożeni niech przypominają wszystkim dzieka-
} nom, aby wszyscy bracia, od najmłodszego aż po najstarszego, zbierali się w niedziele w klasztorze na jednym miejscu. Przed uroczystymi ofiarami Mszy niech opat dokładnie ich wypyta, czy przypadkiem któregoś nie dręczy nienawiść przeciw drugiemu albo nie rani go pocisk złośliwości, aby czasem wewnętrzny jad nie sączył się jakimś ujściem na powierzchnię skóry i między owocami palm nie pojawiła się gorycz mirry. Najpierw więc niech opaci ze swymi przełożonymi oraz dziekanami zbadają samych siebie, podobnie jak badają poddaną sobie młodzież zakonną i we wspomnianych wyżej dniach z korzeniami usuną ze swego serca wszelki kwas złośliwości”. 
w Pakcie słowa kierowane do opata: ,jeśli chciałbyś [...] jednego z nas traktować niesprawiedliwie albo z pychą czy też ze złośliwością, lub jednego otwarcie miłować a drugim gardzić [...], albo jednemu rozkazywać, drugiemu z kolei pobłażać, [...] wówczas posiadamy od Boga dane prawo, aby jedna dekania złożyła skargę u naszego przełożonego, i to bez żadnej buty i złośliwości" 62 . Gdyby jednak opat nie przyjął stawianych mu zarzutów, mnisi mieli prawo powiadomienia o tym pozostałe klasztory lub biskupa, albo też katolickiego obrońcę Kościoła ${ }^{63}$.

\section{Troska opata o starszych i chorych}

Szczególne miejsce w klasztorach fruktuozjańskich należało do starszych i chorych. Świadczy o tym chociażby zapis pozostawiony w Regule mnichów św. Fruktuoza: „Opat lub przełożony powinien korzystać z porad wspomnianych starców we wszystkich ważnych dla klasztoru rzeczach i zawsze prosić ich o opinię we wszelkich nowych sprawach, które się pojawiają"64. Wynika z tego, że nie tylko poszczególni bracia winni okazywać szacunek starszym i wysłuchać ich rady, ale także najważniejsze osoby w klasztorze, opat i przełożony, mają w taki sam sposób ich traktować.

Chorzy i słabi mieszkańcy klasztoru posiadali pewne przywileje, jak chociażby możliwość przyjmowania lepszych posiłków i zamieszkiwania w osobnej celi. Reguła św. Fruktuoza zawiera w tym względzie wyraźny przepis, który odnosił się do starszych zakonników. Czytamy, że „mnichów, którzy po prawym i pobożnym życiu zestarzeli się w klasztorze, należy umieścić osobno, w bardziej przestronnej celi, razem z usługującymi im [braćmi], wybranymi przez opata" ${ }^{95}$. Dbano też o to, by nicze-

\footnotetext{
62 Pactum.

63 Por. Pactum.

64 Regula monachorum XXIII.

65 Regula monachorum XXIII.
} 
go im wówczas nie brakowało. Św. Fruktuoz do poprzedniego przepisu dodaje, że ,gdy [starcy] staną się słabi i zniedołężniali, trzeba im w owej celi przygotowywać na godzinę szóstą posiłek. Stół należy tak zastawić, że będzie jadł spośród nich ten, który zechce. Nie wolno zaś zmuszać do jedzenia nikogo, który nie chce jeść" ${ }^{66}$. Nie tylko zatem choroba i związana z nią słabość ciała dawały większe możliwości, co przede wszystkim starość i fizyczne niedomaganie nakazywały szczególną opiekę nad takimi osobami. Nie traktowano tego jako przywilejów, co raczej w kategoriach naturalnego przychodzenia z pomocą tym, którzy byli już słabi i zmęczeni ${ }^{67}$.

Swoistym przywilejem, jakim cieszyli się starsi mieszkańcy klasztoru, była troska o ich posłanie. W piśmie Reguła wspólna należącym do dokumentów monastycyzmu fruktuozjańskiego czytamy: „Łóżko jednak zalecamy nakryć skórą albo matą (correo aut psiato), która zwie się po łacinie storia [słomianka], czy też w końcu drobną słomą, jeśli nie ma czego innego. Nie dotyczy to chorych i kruchych z powodu zbytniej starości, którzy niech doznają opieki wedle osądu opata" ${ }^{68}$. Podczas gdy mnisi wyrzekali się wygodnego miejsca spoczynku, to starsi i słabi posiadali przywilej lepszego posłania ze względu na swój wiek i dolegliwości. Należy jednak zwrócić uwagę, że decydował o tym opat, a nie schorowany i starszy mnich ${ }^{69}$.

Opat miał też upominać chorych, gdyby ci narzekali i skarżyli się na cokolwiek, tym bardziej, że starano się im zapewnić wsparcie oraz wszystko, czego potrzebują ${ }^{70}$.

\footnotetext{
66 Regula monachorum XXIII.

${ }^{67}$ Por. B. Czyżewski, Reguty iberyjskie o starcach i chorych $w$ klasztorze, „Życie konsekrowane" 5/139 (2019) s. 53.

68 Regula communis XIX.

${ }^{69}$ Por. Czyżewski, Reguty iberyjskie o starcach i chorych w klasztorze, s. 54-55.

70 Por. Regula communis VII.
} 


\section{Podsumowanie}

Z treści przepisów Regut pochodzących z kręgu monastycyzmu fruktozjańskiego wynika, że funkcja opata, podobnie jak w innych klasztorach, była znacząca. W strukturze klasztornej stał on bowiem na czele zakonu i odpowiadał za wiele rzeczy. Nie była to jednak władza absolutna, ponieważ mogliśmy się przekonać, że nader często mowa jest o praepositi, czyli o przełożonych, którzy mieli wspomagać opata. Nie chodziło chyba o ograniczenie jego władzy, co raczej o pomoc w znoszeniu trudów życia. Było zaś ich bardzo wiele, jak chociażby troska o modlitwę w klasztorze, o chorych i starszych mnichów, wysłuchiwanie grzechów i poddawanie ich sprawiedliwemu osądowi, przywracanie mnichów ekskomunikowanych na łono wspólnoty. We wszystkich tych zadaniach potrzebna była cierpliwość, pokora, a przede wszystkim miłość i miłosierdzie. Opat miał być przecież dla mnichów jak ojciec.

Należy też podkreślić, że klasztory fruktuozjańskie wykazywały pewne tendencje „demokratyczne”. Polegały one na odpowiedzialności za życie w klasztorze nie tylko opata, ale także przełożonych i starszych. Kary na mnichów nakładał opat i starsi. Kiedy przyszło podjąć ważne decyzje, nie czynił tego sam opat, ale zapadały one na radzie braci. Demokracja w klasztorach fruktuozjańskich przejawiała się także w tym, że istniał związek pomiędzy klasztorami. Polegał on na tym, że opaci spotykali się, być może raz w miesiącu, by zapewnić wspólną dyscyplinę w podległych im klasztorach.

Reguly zwracają uwagę na wysokie kwalifikacje moralne i duchowe opatów. Musieli wykazywać się przymiotami, które odróżniały ich od pozostałych. Opat nie był też osobą ,nie do ruszenia”. W przypadku niesprawiedliwego postępowania $\mathrm{z}$ jego strony poddawany był osądowi mnichów, w dalszej zaś instancji osądowi biskupa.

Nie wolno też zapominać o wpływie monastycyzmu wschodniego na prawodawstwo monastyczne kręgu św. Fruktuoza z Bragi. Najwięcej 
korzystał on z Reguty św. Pachomiusza i Institutiones św. Jana Kasjana. Dostrzec można także wpływ Reguły św. Izydora z Sewilli, refleksje na temat życia zakonnego św. Hieronima, znane mu również było prawodawstwo św. Benedykta, opata.

\section{The Tasks of the Abbot as Defined in the Monastic Rule from the Circle of Saint Fructuosus of Braga}

(summary)

The object of the study are the monastic writings attributed to the circle of St. Fructuosus of Braga. One of those writings - Rule for the Monastery came from under the pen of Fructuosus, while other originated in his time. They convey an image of monastic life on the Iberian Peninsula. In the organizational structure of the monastery the most important person was the abbot (abbas) whose duties are precisely defined in the Rules. He had to have high moral and intellectual qualifications, was responsible for the prayer in the monastery of which he was in charge, as well as for each of the monks. He often shared his duties with superiors, a measure that to an extent restricted his authority. The abbot also showed some democratic tendencies which were in a sense imposed on him by the Rules. The abbot shared with the superiors and elders the responsibility for the life of the monastery, the abbot and the elders inflicted punishments on the monks, whereas important decisions were taken by the so-called council of brothers. Democracy in Fructuosian monasteries also manifested itself in the ties between the monasteries, consisting in the meeting of abbots perhaps once a month in order to safeguard a common discipline in their subordinate monasteries.

Keywords: abbot; rule; choice; humility; monastery

\section{Zadania opata określone w prawodawstwie monastycznym kręgu św. Fruktuoza z Bragi}

(streszczenie)

Przedmiotem opracowania są pisma monastyczne zaliczane do kręgu św. Fruktuoza z Bragi. Jedno z nich - Reguła mnichów - wyszło spod pióra Fruktuoza, pozostałe powstały za jego czasów. Zawierają one obraz życia monastycznego na Półwyspie Iberyjskim. W strukturze organizacyjnej klasztorów najważniejszy był opat (abbas), którego zadania zostały dosyć dokładnie określone. Musiał posiadać wysokie kwalifikacje moralne i intelektualne, odpowiedzialny był za modlitwę w podległym mu klasztorze, ale też za każdego mnicha. Swoje obowiązki dzielił często z przełożonymi, przez co jego władza została nieco ograniczona. Opaci wykazywali się także postawami demokratycznymi, które w pewnym sensie zostały im narzucone przez Reguly. Polegały one na tym, że wraz 
z przełożonymi i starszymi dzielili odpowiedzialność za życie w klasztorze, opat i starsi nakładali na mnichów kary, ważne zaś decyzje zapadały na tak zwanej radzie braci. Demokracja w klasztorach fruktuozjańskich przejawiała się także w tym, że istniał związek pomiędzy klasztorami. Polegał on na tym, że opaci spotykali się, być może raz w miesiącu, by zapewnić wspólną dyscyplinę w podległych im klasztorach.

Słowa kluczowe: opat; reguła; wybór; pokora; klasztor

\section{Bibliografia \\ Źródla}

Benedictus, Regula, ed. A. De Vogüé, SCh 181-182, Paris 1972, tł. B. Turowicz, Reguła św. Benedykta, w: Reguła Mistrza. Reguła św. Benedykta, ŹM 40, Kraków 2006, s. 387-503.

Boon A., Pachomiana latina, Louvain 1932, s. 169-182, PL 23, 65-90, tł. A. Bober W. Miliszkiewicz - M. Starowieyski, Pachomiana latina, ŹM 11, Kraków 1996.

Cassianus, De institutis coenobiorum et De octu principalium vitiorum remediis libri XII, ed. J.-C. Guy, SCh 109, Paris 2011.

Fructuosus Bracarensis, Regula monachorum, ed. J. Campos Ruiz, w: Santos Padres Españoles, BAC 321, Madrid 1971, s. 137-162, tł. P. Wygralak, Świętego Fruktuoza Reguła mnichów, w: Zachodnie reguły monastyczne, red. M. Starowieyski, ŹM 50, Kraków 2013, s. 1049-1076.

Fructuosus Bracarensis, Regula monastica communis, ed. J. Campos Ruiz, w: Santos Padres Españoles, BAC 321, Madrid 1971, s. 172-208, tł. A. Strzelecka, Reguła wspólna, w: Zachodnie reguły monastyczne, red. M. Starowieyski, ŹM 50, Kraków 2013, s. 1077-1118.

Hieronymus, Epistulae, Hieronim ze Strydonu, Listy, t. 1, opr. M. Ożóg - H. Pietras, ŹMT 54, Kraków 2010.

Isidorus Hispalensis (ep.), Regula monachorum, ed. J. Campos Ruiz, w: Santos Padres Españoles, BAC 321, Madrid 1971, s. 90-125, tł. I. Gano, Ksiega reguły klasztornej, w: Zachodnie reguly monastyczne, red. M. Starowieyski, ŹM 50, Kraków 2013, s. 993-1029.

Pactum, ed. J. Campos Ruiz, w: Santos Padres Españoles, BAC 321, Madrid 1971, s. 208-211, tł. A. Strzelecka, Pakt, w: Zachodnie reguly monastyczne, red. M. Starowieyski, ŹM 50, Kraków 2013, s. 1119-1123. 


\section{Opracowania}

Bishko Ch.J., Fructuosus of Braga, w: Medieval Iberia. An encyclopedia, New York 2003, s. 342-343.

Czyżewski B., Funkcje w Klasztorze Honoriańskim na podstawie Reguły św. Izydora z Sewilli, „Studia Gnesnensia” 39 (2015) s. 173-181.

Czyżewski B., Reguły iberyjskie o starcach i chorych w klasztorze, „Życie konsekrowane" 5/139 (2019) s. 45-57.

Díaz y Díaz M.C., Fructueux de Braga (saint), „Dictionnaire de Spiritualité”, t. 5, M. Viller, Paris 1964, s. 1541-1546.

Díaz y Díaz M.C., La vida de San Fructuoso de Braga: estudio y edición critica, Braga 1974.

Drączkowski F., Fruktuoz, EK V 729.

Gregoire R., Valeurs ascétiques et spirituelles de la Regula monachorum et de la Regula communis de s. Fructueux de Braga, ,Revue d'ascétique et de mystique” 43 (1967) s. 159-178.

Herwegen I., Das Pactum des hl. Fructuosus von Braga, Stuttgart 1907.

Linage Conde A., El torno de la Regula monachorum y sus relaciones con otras Reglas monásticas, „Bracara Augusta” 22 (1968) s. 123-163.

Linage Conde A., San Benito y las fuentes literarias de la obra monástica de Fructuoso de Braga, Studia Patristica XIX-XXIII, Leuven 1989, s. 264-273.

Martins M., O monacato de S. Fructuoso de Braga, „Biblos” 26 (1950) s. 315-420.

Pérez de Urbel J., Regula complutensis (Regula S. Fructuosi), w: DIP VII 1759-1771.

Pettiau H., La Vie de saint Fructueux de Braga: Quelques aspects de la relation entre l'ascète et la société en Espagne wisigothique, w: Corona Monastica: moines bretons de Landévennec, histoire et mémoire celtiques: mélanges offerts au père Marc Simon, ed. L. Lemoine - B. Merdrignac - A. Calarnou, Britannia Monastica 8, Landévennec 2004, s. 57-69.

Quiroga J.L., Actividad Monástica y acción política en Fructuoso de Braga, „Hispania sacra. Revista española de historia ecclesiástica" 54 (2002) s. 7-22.

Starowieyski M., Fruktuoz, bp Bragi, NSWP, Poznań 2018, s. 374-375. 
Starowieyski M., Monastycyzm na Półwyspie Iberyjskim, w: Zachodnie reguły monastyczne, ŹM 50, Tyniec 2013, s. 903-914.

Starowieyski M., Prawodawstwo monastyczne kręgu św. Fruktuoza z Bragi. Wstęp, w: Zachodnie reguły monastyczne, ŹM 50, Tyniec 2013, s. 1031-1047. 